\title{
Study on the Ecological Footprint of Real Estate Development Companies and Its Influencing Factors:Based on China's Provincial Datas
}

\author{
Ying Zhang 1, a , Ying Gu ${ }^{2, b}$ \\ ${ }^{1,2}$ School of Business, Central South University,Changsha 410083,China \\ azhang@csu.edu.cn, bgy_assun@163.com
}

\begin{abstract}
Keywords:sustainable development;ecological footprint;real estate development companies; influencing factors
\end{abstract}

Abstract.The ecological footprint theory provides a quantitative evaluation method for the sustainable development of real estate development companies .Based on the ecological footprint model and national hectare, combining with the characteristics of real estate development companies, this study calculates the ecological footprint of real estate development companies (EFr) in China's 31 provinces during 2001-2014. The EFr per unit of output for all regions decline year by year.At the same time,by using the fixed effects panel data model, this study empirically tests the influencing factors of the EFr.The results show that the Environmental Kuznets Curve is existent and the added value of real estate industry and foreign direct investment have positive impacts on the EFr, while the effects of the lagging environment regulation and business performance are negative.At last, several suggestions are provided,which can be the theoretical and practical references for the sustainable development of real estate development companies.

\section{Introduction}

Since the 1980s, China's real estate industry has entered a high-speed development period, and a large number of real estate development companies arise at the historic moment. The real estate industry has become one of the most important pillar industries of national economy in China. Unfortunately, however, not only does this high real estate development rate exert an impact in the economy,but it also causes an impact on the China's environment, which has yet to be evaluated. To a great extent,the contribution of the real estate industry to promote the China's economy is at the cost of a large amount of resource consumption and pollutant emissions.As a result,it brings a serious damage to the local environment so that the sustainable development of real estate development companies will be threatened.Therefore, in the pursuit of improving the environmental performance of the real estate development companies and promoting its sustainable development,it is necessary to understand the stress level which is caused by the real estate development companies and explore its influencing factors. The economic development is important,at the same time,the "environmentally friendly" development strategy can also not be ignored.

At present,the economic impact of the real estate development companies is well known.However,little has been done to measure its environmental impact.Expecially, the quantitative researches on the sustainable development of real estate development companies are fewer than qualitative researches.Although several methodologies of environment assessment can be applied such as emergy analysis [1] and material flow analysis [2],there is a simpler methodology which can be more easily understood by society.It is the ecological footprint which can be adapted to unique characteristics of the behaviors of the real estate development companies, and has been chosen for its comprehensibility,transparency, and adaptability [3-4].

The ecological footprint indicator was introduced by Wackernagel and Rees in the 1990s, who measured the ecological footprint of humanity and compared it with the carrying capacity of the planet to evaluate the environmental sustainability.According to its definition, the ecological footprint is the amount of land that would be required to provide the resources(grain,fish,and so on)and absorb the emissions of humanity [5-6].In 2008, the concept of the sustainable development of real estate 
development was firstly used in China. They defined the ecological footprint of the real estate development as the impact of real estate development measured in terms of biologically productive land to produce the goods consumed and to assimilate the wastes generated [7].

In this study,the ecological footprint of real estate development companies in China's 31 provinces is studied by applying the procedure developed by researchers [8-10] on ecological footprint calculation and on the process of real estate development.

In the following sections that introduce the methodological analysis for real estate development companies and the influencing factors of the ecological footprint of real estate development companies.Among them,the whole methodology is explained using five aspects:the ecological footprint of manpower,materials,land,construction waste and enery. An approach to the calculation of the ecological footprint of real estate development companies, valid for any real estate development companies,is described in detail therein.Finally, the results from the study will be shown and expressed.

Partial and total footprints,generated in the construction phase of real estate development,are defined by means of the intermediate elements and their corresponding coefficients.In the calculations, up-to-date equivalence factors [11] must be considered,in order to transform the results expressed into national hectares over hectares(nha).Referring to the previous researches,combining with emergy analysis [12-13],these equivalence factors are calculated.They are shown in Table 1.

Table 1

Equivalence factors

\begin{tabular}{ll}
\hline Productive land category & Equivalence factor(nha/ha) \\
\hline Cropland & 4.89 \\
Pastures & 0.06 \\
Forest & 0.29 \\
Productive sea & 0.06 \\
Built land & 4.89 \\
Fossil energy land & 0.29 \\
\hline
\end{tabular}

\section{Methodology}

In order to calculate the ecological footprint of real estate development companies,it is necessary to establish the functional unit of the study.Currently,the global hectar is used widely.However,considering the fact situation,this study uses the national hectar [14] as the unit so that it can reflect the situation better.What' $s$ more,it' $s$ not equivalent between a kilo of grain and a kilo of pork so that the emergy analysis is applied in the following calculations.

In this study,the analysis of the ecological footprint of real estate development companies focuses mainly on the construction phase of real estate development. The first resource is the materials,mainly including three types:steel,wood and cement.The second resource is the land.Obviously, the materials and built land are not the only resources consumed during the real estate development. Three additional resources:manpower,construction waste and energy also generate ecological footprint.Each resource consumed can be described in the form of ecological footprint.

\section{Determination of the Ecological Footprint of Manpower:Food Consumption}

The initial assumption of this section is that the workers' food is attributed to the ecological footprint of real estate development companies since this activity takes place during the real estate development period.The business meals can refer to the main food consumption of Chinese. Then, the average number of manpower hours for the real estate development should be calculated, which can be obtained by official statistics.

The footprint is calculated using the expression: 


$$
\mathrm{EF}_{\mathrm{L}}=\left(\frac{\mathrm{C}_{\mathrm{i}}}{\overline{\mathrm{EP}_{\mathrm{i}}}} \cdot \mathrm{r}_{\mathrm{j}} \cdot \mathrm{N} \cdot \mathrm{T}\right) / 168
$$

where $\mathrm{EF}_{\mathrm{L}}$ :weighted the ecological footprint of manpower(nha/year), $\mathrm{C}_{\mathrm{i}}$ :per capita consumption of the kind of resource i, $\overline{E P_{i}}$ : average unit productivity of the kind of resource i,produced by the kind of ecological productive land $\mathrm{j}, \mathrm{r}_{\mathrm{j}}$ :equivalence factors(nha/ha), $\mathrm{N}$ :the professionals of the real estate development companies,T:the average working hours per week of the professionals, 168:the hours of a week.

\section{Determination of the Ecological Footprint of Materials Consumption}

Kinds of materials are consumed in this sector,including steel, wood, cement,glass and so on.Among them,the first three materials are used most,so they are the key research objects to this study.Instead of floor space completed,the floor space under construction is more aligned with the actual workload.Expecially, the consumption of the materials can be obtained on the basis of cost indexes of construction and the floor space under construction.

The ecological footprint of materials is determined as follows:

$$
\mathrm{EF}_{\mathrm{M}}=\mathrm{S}_{\mathrm{m}} \cdot \frac{\mathrm{C}_{\mathrm{i}}}{\overline{\mathrm{EP}}} \cdot \mathrm{r}_{\mathbf{j}}
$$

where $\mathrm{EF}_{\mathrm{M}}$ :weighted the ecological footprint of materials(nha/year), $\mathrm{S}_{\mathrm{m}}$ : the floor space under construction of real estate development companies(ha/year), $\mathrm{C}_{\mathrm{i}}$ :the consumption of the kind of material i per unit floor space under construction, $\overline{E P}$ : average unit productivity of the kind of material i , $r_{j}$ :equivalence factors(nha/ha) .

\section{Determination of the Ecological Footprint of Land}

Not only the land occupied directly by real estate development,but also the construction land including the road,virescence region and so on should be considered.So the plot ratio is applied in order to calculate the total area of used land.The datas of plot ratio are obtained from typical projects of real estate development companies in every province.For example, in 2014, the average plot ratio of residence is 2.5 , the average plot ratio of office building and business building is 5.3.

The ecological footprint of land is:

$$
\mathrm{EF}_{\mathrm{I}}=\frac{\mathrm{S}_{\mathrm{k}}}{\mathrm{FAR}_{\mathrm{k}}} \cdot \mathbf{r}_{\mathrm{j}}
$$

Where EFr:weighted the ecological footprint of land(nha/year),k:the type of real eatate development(residence, office building and business building), $S_{\mathrm{k}}$ :the area of structure of real eatate development,type $\mathrm{k}, \mathrm{FAR}_{\mathrm{k}}$ :the plot ratio of type $\mathrm{k}, \mathrm{r}_{\mathrm{j}}$ :equivalence factors(nha/ha) .

\section{Determination of the Ecological Footprint of Construction waste}

In this section,the environmental impact of construction waste is analyzed.Mixed construction waste groups together the remains of materials generated during the execution of real estate development. As shown in previous researches, when the area of structure is 10000 square meters ,approximately 500-600 ton of construction waste are generated.0.067 square meters will be occupied where 1000 kilograms of construction waste are stored.

The ecological footprint of construction waste is determined using the following expression: 


$$
\mathrm{EF}_{\mathrm{W}}=\frac{\mathrm{S}_{\mathrm{m}}}{10000} \cdot 600 \cdot 0.067 \cdot 10^{4} \cdot \mathrm{r}_{\mathrm{j}}
$$

where $\mathrm{EF}_{\mathrm{w}}$ :weighted the ecological footprint of construction waste(nha/year), $\mathrm{S}_{\mathrm{m}}$ : the floor space under construction of real estate development companies(square meters/year), $\mathrm{r}_{\mathrm{j}}$ equivalence factors(nha/ha) .

\section{Determination of the Ecological Footprint of Energy Consumption}

Energy is one of the primary resources consumed during the construction period of real estate development. As concluded in previous researches, approximately $50 \%$ of the total consumption of the energy is used in the process.In order to calculate the sector better,this study adopts the method of carbon sinks which describes the absorption of $\mathrm{CO}_{2}$ produced by energy consumption. Then translate it into ecological productive land area to measure the ecological footprint.

As a hypothesis,the total energy consumption of the execution of the real estate development is considered to be shared out between electricity and fuel consumption [15].Therefore,once the total energy consumption and one consumption are determined, then the other consumption can be obtained by the difference between these quantities. The total energy consumption can be obtained by the product between per unit GDP energy consumption and the added value of real estate industry of China' s 31 provinces.Similarly,the electricity consumption is also obtained.Then the fuel consumption (gasoline and diesel) is determined.Combining all kinds of energy consumption and their coefficients of carbon dioxide emissions [16], the total carbon dioxide emissions can be obtained.

The formula used is:

$$
E F_{n}=P_{c} \cdot\left(1-S_{o c e a n}\right) \cdot r_{j} / S_{c}
$$

where $\mathrm{EF}_{\mathrm{n}}$ :weighted the ecological footprint of energy consumption(nha/year),Pc: the total carbon dioxide emissions generated by energy consumed(t), Socean:the carbon dioxide emissions absorbed by $\operatorname{sea}(30 \%)$ [17], $\mathrm{r}_{\mathrm{j}}$ :equivalence factor of forests(nha/ha),Sc:the average absorption of the carbon dioxide by forests(3.5926t/ha) .

\section{Determination of the Ecological Footprint of Real Estate Development Companies}

As above, the ecological footprint of real estate development companies is consist of five parts:the ecological footprint of manpower,materials consumption,land,construction waste,and energy consumption.Using the relevant datas, the ecological footprint of real estate development companies in China' s 31 provinces during 2001-2014 can be calculated.Considering the limited space of the paper,the calculation results will be shown every four years in Table 2.

In Table 2, the EFr go up for all real estate development companies in most provinces year by year.To explore the study further,the EFr per unit of output measured by the ratio of the ecological footprint of real estate development companies to the added value of real estate industry. The result shows that the EFr per unit of output for all regions decline year by year.It means that the real estate development companies have done some effective contribution to relieve the environmental impact of real estate development with the development of real estate industry.

\section{Empirical Research}

Currently, the sustainability of real estate development companies is facing some big challenges.But the companies have to wrestle with them.To come to some ideas of where the answers lie, it is necessary to realize the influencing factors of the ecological footprint of real estate development 
companies.In previous researches, several influencing factors are discussed [18-19].Considering the characteristics of real estate development companies, there are several factors included in this study:the added value of real estate industry,foreign direct investment,environment regulation, and business performance.At the same time, the quadratic term of the added value of real estate industry is also applied to verify the Environmental Kuznets Curve Hypothesis.

Table 2

The ecological footprint of real estate development companies(nha)

\begin{tabular}{|c|c|c|c|c|c|c|c|c|c|}
\hline $\begin{array}{c}\text { region } \\
\text { year }\end{array}$ & 2002 & 2006 & 2010 & 2014 & region & 2002 & 2006 & 2010 & 2014 \\
\hline Beijing & 7284657 & 6381023 & 4951273 & 5056363 & Hubei & 2890949 & 3671119 & 5314697 & 9442719 \\
\hline Tianjin & 2425148 & 2664407 & 3284027 & 3827216 & Hunan & 2407139 & 4091979 & 7242540 & 9318254 \\
\hline Hebei & 2491698 & 3432128 & 9237915 & 11178141 & Guangdong & 13247202 & 12587473 & 14728826 & 20680328 \\
\hline Shanxi & 1114668 & 2027504 & 3330662 & 5465356 & Guangxi & 1429670 & 3000981 & 5253474 & 6030892 \\
\hline $\begin{array}{c}\text { Inner } \\
\text { Mongolia }\end{array}$ & 1200575 & 2313495 & 5020507 & 6260871 & Hainan & 297767 & 633185 & 1332348 & 2701187 \\
\hline Liaoning & 5240139 & 5401464 & 11720145 & 13628245 & Chongqing & 4581646 & 5156480 & 6989906 & 9513608 \\
\hline Jilin & 1653758 & 1894273 & 3130519 & 4375510 & Sichuan & 5771100 & 6587018 & 8985546 & 11966769 \\
\hline $\begin{array}{c}\text { Heilong } \\
\text { jiang }\end{array}$ & 1897585 & 2127215 & 3499159 & 5081963 & Guizhou & 1832215 & 2031029 & 3186237 & 6437501 \\
\hline Shanghai & 7719316 & 7105863 & 5477042 & 5795357 & Yunnan & 1390811 & 2188115 & 3769520 & 6392889 \\
\hline Jiangsu & 7257708 & 12428807 & 17237672 & 21840164 & Tibet & 27340 & 86011 & 52336 & 113865 \\
\hline Zhejiang & 8632984 & 10588994 & 10762247 & 14110990 & Shaanxi & 2079981 & 2270802 & 4473143 & 6960444 \\
\hline Anhui & 2811578 & 4515698 & 7815165 & 11472712 & Gansu & 749383 & 1036591 & 1403507 & 2683706 \\
\hline Fujian & 4476045 & 4523536 & 6140890 & 9952562 & Qinghai & 375441 & 297076 & 606966 & 850041 \\
\hline Jiangxi & 2015268 & 2971745 & 3405071 & 4811878 & Ningxia & 486089 & 704146 & 1241659 & 2305346 \\
\hline Shandong & 6380875 & 8568297 & 13451305 & 19956636 & Sinkiang & 1366379 & 1046017 & 1821196 & 3913481 \\
\hline Henan & 2996867 & 4711255 & 9281665 & 14075467 & & & & & \\
\hline
\end{tabular}

\section{Unit root test}

As the most essential step in an econometric analysis, unit root test is very important.It is utilized to test the stationarity of the variables, as a variable cannot be used in the analysis if it is not stationary. A variable is said to be stationary if its mean and autocovariances do not depend on time.There are four types of unit root tests are widely used, namely,Levin,Lin and CHU(LLC)(2002),Im, Pesaran and Shin (IPS) (2003),Fisher-type ADF and PP unit root tests proposed by Maddala and Wu (1999) and Choi(2001).

The LLC,IPS, ADF and PP tests work under the null hypothesis of a unit root and the alternative hypothesis of no unit root.The test results shown in Table 3 mean that the unit root is nonexistent,so the variables in this study are stationary.

Econometric model

For our purposes in this sector,we concentrate on the influencing factors of the ecological footprint of real estate development companies(EFr).So in this study, the EFr is the dependent variable, and the influencing factors are independent variables.Expecially,considering the time-lag effect of environment regulation, the lagging environment regulation is also used in the econometric model.

Consider the following econometric model, which is the basis of our analysis: 
$\ln \mathrm{EFr}={ }_{\mathrm{a}}+\beta_{1} \ln \mathrm{V}+\beta_{2} \ln ^{2} \mathrm{~V}+\beta_{3} \ln \mathrm{FDI}+\beta_{4} \ln \mathrm{EI}_{\mathrm{t}}+\beta_{5} \ln \mathrm{EI} \mathrm{I}_{\mathrm{t}-1}+\beta_{6} \mathrm{r}+\mu$

where EFr:the ecological footprint of real estate development companies, V:the added value of real estate industry,FDI:level of foreign direct investment,measured by the ratio of actual datas of foreign direct investment to the added value of real estate industry,EI:a comprehensive index that measures the level of environment regulation,measured by the entropy method,combining with several ralated indicators,including wastewater effluent(0.07),sulfur dioxide emissions(0.04),soot emissions(0.04),industrial waste gas emission(0.03), industrial solid wastes( 0.05$)$, the ratio of the investment to environmental pollution control to $\operatorname{GDP}(0.4)$, and decontamination rate of urban refuse(0.37)(figures in the parentheses are weight coefficients of the indicators),r:the business performance of real estate development companies,measured by total assets profit rate, $\mu$ :stochastic error,t:the periods of the study.

Eq.(6) is estimated via the fixed effects panel data model.The type of model is determined using Likelihood ratio test and Hausman test.The test results are shown in Table 4.Because the Chi-square is significant at the $1 \%$ level,the fixed effects panel data model is more optimal than random effects model for the analysis.

Table 3

The test results of unit root test

\begin{tabular}{|c|c|c|c|c|}
\hline & LLC & IPS & ADF-Fisher & PP-Fisher \\
\hline \multirow{2}{*}{ Ln EFr } & $-12.2246^{* * *}$ & $-3.31782^{* * *}$ & $77.3310^{* * *}$ & $102.421^{* * *}$ \\
& $(0.0000)$ & $(0.0005)$ & $(0.0004)$ & $(0.0000)$ \\
\hline \multirow{2}{*}{ Ln V } & $-9.14301 * * *$ & $-2.75927 * * *$ & $78.1186^{* * 8}$ & $97.1748^{* * *}$ \\
& $(0.0000)$ & $(0.0029)$ & $(0.0003)$ & $(0.0000)$ \\
\hline \multirow{2}{*}{ Ln $^{2} \mathrm{~V}$} & $-7.49361^{* * *}$ & -0.67405 & $61.4856^{* *}$ & $71.5898^{* * *}$ \\
& $(0.0000)$ & $(0.2501)$ & $(0.0161)$ & $(0.0016)$ \\
\hline \multirow{2}{*}{ Ln FDI } & $-6.83457 * * *$ & $-3.70417 * * *$ & $79.9700^{* * *}$ & $77.3515^{* * *}$ \\
& $(0.0000)$ & $(0.0001)$ & $(0.0002)$ & $(0.0004)$ \\
\hline \multirow{2}{*}{ Ln EI } & $-8.87700^{* * *}$ & $-1.65514 * *$ & $61.7989 * *$ & $69.2686^{* *}$ \\
& $(0.0000)$ & $(0.0489)$ & $(0.0150)$ & $(0.0028)$ \\
\hline \multirow{2}{*}{$\mathrm{r}$} & $-5.83990^{* * *}$ & $-2.94628^{* * *}$ & $69.2161 * * *$ & $83.3397 * * *$ \\
& $(0.0000)$ & $(0.0016)$ & $(0.0028)$ & $(0.0001)$ \\
\hline
\end{tabular}

statistical significance in parentheses

$* \mathrm{p}<0.10, * * \mathrm{p}<0.05, * * * \mathrm{P}<0.01$

Table 4

The test results of Likelihood ratio test and Hausman test

\begin{tabular}{llll} 
& & Statistic & Prob. \\
\hline Hausman test & Chi-square & 30.786203 & $0.0000^{* * *}$ \\
Likelihood ratio test & $\mathrm{F}$ & 3.092110 & $0.0010^{* * *}$ \\
& Chi-square & 31.162052 & $0.0006^{* * *}$ \\
\hline
\end{tabular}

Regression results 
As the variables are observed to be stationary, and the fixed effects panel data model is determined, the next step in the analysis is to examine the correlation between the dependent and independent variables by utilizing the multivariate regression analysis. The regression results are displayed in Table 5.

The results show that except the current environment regulation,every independent variable in this study has a significant effect on the ecological footprint of real estate development companies. Specifically,the added value of real estate industry and foreign direct investment have positive impacts on the EFr, while the effects of the lagging environment regulation and business performance are negative.At the same time, the results also verify the Environmental Kuznets Curve Hypothesis.

Table 5

The regression results

\begin{tabular}{|c|c|c|c|}
\hline Variable & Coefficient & t-Statistic & Prob. \\
\hline Constant term & 9.520756 & 17.69129 & $0.0000^{* * *}$ \\
\hline $\ln \mathrm{V}$ & 1.416096 & 8.164540 & $0.0000^{* * *}$ \\
\hline $\mathrm{Ln}^{2} \mathrm{~V}$ & -0.058344 & -4.168334 & $0.0000^{* * *}$ \\
\hline $\operatorname{lnEI} \mathrm{t}$ & -0.095662 & -0.487893 & 0.6261 \\
\hline $\operatorname{lnEI} \mathrm{t}-1$ & -0.454978 & -2.120869 & $0.0350^{* *}$ \\
\hline $\operatorname{lnFDI}$ & 0.047291 & 3.520473 & $0.0005^{* * *}$ \\
\hline $\mathrm{r}$ & -0.066912 & -2.626929 & $0.0092^{* * *}$ \\
\hline \multicolumn{2}{|c|}{} \\
\hline
\end{tabular}

\section{Conclusions and suggestions}

The ecological footprint of real estate development companies is estimated sucessfully which can be used to evaluate the sustainability of real estate development companies. The results show that the EFr per unit of output for all regions decline year by year.Meanwhile,to promote the sustainable development of real estate development companies,several effective measures are obtained basis of the influencing factors of the EFr.

The added value of real estate industry has a positive and significant effect on the EFr.Its effect mainly depends on two ways:directness and indirectness.For the former,with the increasing of the added value of real estate industry,more number of resources are needed,which can add the level of the EFr.As for the latter,with the increasing,some changes of several other factors will happen,for example,the improved technology which can reduce the level of the EFr.Obviously,in this study,the increasing of the former is more than the reducing of the latter,so that the positive effect is shown at last.For the real estate companies, the sustainable development is as important as the economic development.It is necessary to keep a moderate development speed which matches the demand of market and the economic development.

The Environmental Kuznets Curve Hypothesis is verified.It describes that with the increasing of the added value of real estate industry,the EFr rises first and goes down latter.Only does the economy come to a certain degree, some favorable factors(such as technology,advanced equipments and so on)will play their roles better.Currently,the economic development level of China's real estate development companies does not get to the inflection point.

The effects of the lagging environment regulation and business performance on the $\mathrm{EFr}$ are negative.The environment regulation is an indictor of time lag , and it can compel the real estate development companies to take some environmental actions,such as using advanced equipments,adopting environmental technologies and so on.In the short run, the severe level of environment regulation may cost a lot,increasing the companies environmental cost which is unfavourable to the companies sustainable development.However,it can improve the companies fundamentally so that the increasing environmental cost can be offset in the long run.The EFr will go down with the increasing level of environment regulation.Similarly, the higher level of business 
performance,the real estate development companies will be more willing and able to take green actions so that the EFr will descend.As the environmental activities are costly but favourable,only the companies of higher level of business performance can afford them. Therefore,for the real estate development companies, they should response to the environment regulation actively, and balance the increasing environmental cost and the business performance.The economic development and the environmental effect are both considered at the same time,with a high cost performance.For example,the evaluation index of ecological efficiency can be utilized in the administrative decisions.

The foreign direct investment has a positive impact on the EFr.As one of the main sources of working capital,it not only can bring large number of capital to promote the development of companies, but it can also increase the local environmental cost because of the pollution transfer [20].In this study,obviously,the effect of the environmental cost is more outstanding.The EFr will go up with the increasing level of foreign direct investment.The suggestions are that discriminate the quality of the foreign direct investments,increase high-quality capital and utilize the advanced technology brought by advanced economies. The development of companies should not be at the cost of environmental pollution.

\section{Acknowledgements}

This work was financially supported by MOE (Ministry of Education in China) Research Project of Humanities and Social Sciences (11YJA790212), Philosophy and Social Science Fund Project of Hunan Province,China (11YBA314), and Teachers Research Project of Central South University (2013JSJJ053).

\section{References}

[1] Meillaud F,Gay J,Brown MT:Solar Energy Vol.79(2005),p.204-212.

[2] Sinivuori P.Saari A:Build Environ Vol.41(2006),p.657-668.

[3] Zhang Jiankun,Gu Jinlei:Inquiry into Economic issues Vol.31(2010),p.106-109.(in Chinese)

[4] Wang Li:Statistics and Decision No.4(2013),p.60-62.(in Chinese)

[5] Wackernagel M,Rees W:Our ecological footprint: Reducing human impact on the earth(New Society Publishers, Gabriola Island 1996).

[6] Rees W E:Environment and Urbanization Vol.4(1992),p.121-130.

[7] Li Dezhi,Li Qiming:Journal of Southeast University Vol.38(2008),p.732-735.(in Chinese)

[8] Luo Xiaomei:Science \& Technology Progress and Policy Vol.32(2015),p.79-85.(in Chinese)

[9] Patricia Gonzalez-Vallejo:Ecological Indicators Vol.52(2015),p.75-84.

[10] Shu Chang,Qiao Juan:Ecological Economy Vol.32(2016),p.148-151.(in Chinese)

[11] Wackernagel M, Rees W E:Ecological Economics Vol.20(1997),p:2-24.

[12]Lei,k.,Zhou,S:Energy policy Vol.42(2012),p:603-612.

[13]Elisa Sayoko Nakajima,Enrique Ortega:Ecological Indicators Vol.60(2016),p:1200-1207.

[14] Gu Xiaowei:Journal of Noutheast University Vol.26(2005),p.295-298.(in Chinese)

[15] Subramanian Senthilkannan Muthu :Assessment of Carbon Footprint in Different Industrial Sectors(Springer,Hong Kong 2014).

[16] Simon Eggleston,Leandro Buendia et al:2006 IPCC Guidelines for National Greenhouse Gas Inventories (IGES, Japan 2006). 
[17]Borucke M,Moode D,Cranston G,et al:Ecological Indicators Vol.24(2013),p:518-533.

[18]Usama Al-mulali,Choong Weng-Wai, et al:Ecological Indicators Vol.48(2015),p:315-323.

[19]Ahmet Atil Asici,Sevil Acar:Ecological Indicators Vol.61(2016),p:707-714.

[20]Taylor,M.S:Advances in Economic Analysis \& Policy Vol.2(2006),p:125-176. 